\title{
E-Entrepreneurship for E-Startups: Potentials, Common Challenges and Way Forward
}

\author{
Mohammad Aminul Islam, Mohammed A Alghobiri \\ King Khalid University, College of Business, Management Information Systems, Abha, Saudi Arabia \\ maleslam@kku.edu.sa, aminul.dhaka@gmail.com, maalghobiri@kku.edu.sa
}

\begin{abstract}
In today's economic world, the advancement in technology has opened up new forms of economic activities, particularly business. Whilst entrepreneurship is a major factor in business, e-entrepreneurship has become a buzzword facilitated by the rapid advancement of internet and developments in Information and Communication Technologies (ICTs). E-entrepreneurship, in the name of transforming business from the local marketplace to the global one, has revolutionized the entire business processes. This set of new business mechanism has created new opportunities for the startups, which in this regard is termed as e-startups. The purpose of this paper, therefore, is to develop a comprehensive understanding of the concept of eentrepreneurship by addressing related potentials and challenges. Extant literature has been reviewed to this end. The analysis indicated that flexibility of and accessibility to technology and products, less capital and risk in comparison to physical businesses are the major advantages that an e-entrepreneur might enjoy while commencing an e-startup. On the other hand, lack of institutional support, digital security threat, tough competition with established brands, less innovation and lack of academic and practical exposure in terms of business and marketing are some barriers that challenge the operation of e-startups. The conclusion of the paper draws on some recommendations accordingly.
\end{abstract}

Keywords: Entrepreneurship, e-entrepreneurship, e-startup, e-business, net economy.

\section{Introduction}

In recent years the ongoing development of internet and technology has changed the way we think of business. Today, information as the means of competitive advantage is more easily accessible and used for commercial purposes due to new business settings shaped by Information Technologies (Kollmann, 2006). These commercial activities can be termed as e-business (Matlay \& Martin, Collaborative and competitive strategies in virtual teams of e-entrepreneurs: A pan-European perspective, 2009) and it forms new entrepreneurial activities called e-entrepreneurship (Kollmann, 2006; Matlay, E-entrepreneurship and small e-business development: towards a comparative research agenda, 2004). In the same process, the wave of estartups is streaming in ways few have contemplated before. It is agreed that potential entrepreneurs lack in liquid capital (Blanchflower \& Oswald, 2007). Today technology has become affordable, reliable and powerful (Hunter \& Long, 2003). In spite of the lack of huge capital, one can start his own business online and can compete with larger businesses. Internet and technology jointly have established practices and new ways of doing business, thus informing and influencing business at regional, national and international levels (Matlay, E-entrepreneurship and small e-business development: towards a comparative research agenda, 2004). Today, e-entrepreneurship observes its tremendous societal importance. E-entrepreneurship, alike traditional entrepreneurship, requires basic business skills and expert knowledge (Zhao, 2007). In this paper, the term e-entrepreneurship refers to those entrepreneurial activities that are operated on the internet (Manuel, 2006). The purpose of this discussion is to identify the advantages and the relevant risks a new eentrepreneur might come across while doing business online. The beginners may find this paper very useful, especially in the context of small business operations. This discussion will also provide the necessary guidance to the relevant stakeholders on "e-entrepreneurship". This paper is basically premised upon an extant literature review. Therefore, starting with a review of the concepts of entrepreneurship and other associated terms, the sections then offers a brief discussion on potentials and challenges a startup might experience and so should address. The paper ends with some strategic recommendations.

\section{Literature Review}

Entrepreneurs bring new businesses to the market (Rumelt, 2005). They are widely viewed as the risk takers and explorers of new opportunities. The concept of entrepreneurship was first established in the $17^{\text {th }}$ century, when an entrepreneur took the risk of profit or loss on a fixed contract with the government (Manuel, 2006) and Richard Cantillon (1680-1734) saw the profit opportunities in buying cheaply and selling at a higher 
price for a group of people called "entrepreneurs" (Landstrom, 2007). The meaning has evolved ever since. While some describe the entrepreneur as a risk-taker of a new venture, others, marking his innovative skills, consider as a developer of new goods, services or processes for profit. Meyer, Neck, \& Meeks (2017) have listed some of the modern definitions of entrepreneurship as below.

\section{Table 1: Modern Definitions of Entrepreneurship}

\section{Author \\ Definition}

Schumpeter (1934)

Kirzner (1973)

Drucker (1985)

Stevenson, Roberts, \& Grousbeck (1985)

Rumelt (1987)

Low \& MacMillan (1988)

Gartner (1988)

Timmons (1997)

Venkataraman (1997)

Entrepreneurship research seeks to understand how opportunities to bring into existence future goods and services are discovered, created, and exploited, by whom, and with what consequences.

Morris (1998)

Entrepreneurship is the process through which individuals and teams create value by bringing together unique packages of resource inputs to exploit opportunities in the environment. It can occur in any organizational context and results in a variety of possible outcomes, including new ventures, products, services, processes, markets, and technologies.

Sharma \& Chrisman (1999)

Entrepreneurship encompasses acts of organizational creation, renewal, or innovation that occur within or outside an existing organization 
Entrepreneurship, on the one hand, is the discovery of opportunities and the creation of new economic activity building a new organization (Reynolds, 2005) and on the other the process of risk-taking of a new business (Hébert \& Link, 1989). Therefore, entrepreneurship is the pursuit of new business opportunities that create wealth in any society.

This is the age of knowledge which is based on the information. The ongoing development of the internet and technology has changed the way of entrepreneurship. A whole range of new ideas and opportunities for entrepreneurship have come up. E-entrepreneurship is the expansion of traditional entrepreneurship in the e-business which incorporates all the key elements of traditional entrepreneurship, including risk-taking, proactivity, innovation, running and managing the e-business (Zhao, 2007). Therefore, the concept of ebusiness comes along with the e-entrepreneurship. IBM was one of the first companies which used the term "E-Business" in 1997 (Sharma, Pathak, \& Chowhan, 2014). E-business deals with buying, selling and managing business-related functions over the internet with a view to satisfy the customers (Matlay \& Martin, Collaborative and competitive strategies in virtual teams of e-entrepreneurs: A pan-European perspective, 2009). A successful e-business organization combines four distinctive elements: leading-edge technologies, long-term business strategies, strategy implementation using technologies, and aligning people's behavior surrounding the business (Sharma, Pathak, \& Chowhan, 2014).

Thus, E-business forms the fundamental construction of e-entrepreneurship (Zhao, 2007). Internet and modern technology not only changed the way of doing business but also established a new economy, i.e. net economy or digital economy. Kollmann (2006) described e- entrepreneurship as the act of establishing new companies in the net economy. Turban, King, Lee, Liang \& Turban (2015) defined net economy as an online platform where business can be operated based on digital technologies and communication networks. The scope of the net economy, thus, has provided the startups, the new ventures, a venue for developing new ideas and turning those ideas into new e-businesses. According to (Finkelstein, 2001), the success of internet startups is determined by four basic factors: customers, capabilities, competitive advantage, and internal consistency. He argues that customers are the heart of all business and a business must develop and retain customers. Startups need to develop unique capabilities that the customer's value and are not easily copied by the rivals. In return business will benefit from the competitive advantage which is supported by its internal system. E-entrepreneurship is becoming more popular these days, as many people are becoming interested in gaining freedom from their traditional employment and so are heading towards e-startups. Rather than working for a company, they are branching out into becoming e-entrepreneurs and becoming their own boss and/or employers. As this trend is growing at a fast rate, it is worthwhile to look at its potentials and challenges.

\section{Potentials}

Small sized businesses are more operative and flexible than big companies. Specific focus on operations may return rewarding outcomes. Today Information and Communication Technologies (ICTs) are the most important factors in doing business in many countries. Business ventures generally anticipate of being successful using the technology they use. E-entrepreneurship, in this regard, is benefited through their direct connection with customers. Without being tied down to a physical location, information work can be done anywhere with a laptop or cell phone crossing time zones to allow business to be monitored anytime, anywhere (McNurlin, Sprague, \& Bui, 2009). Social media email and instant messaging give the opportunity to be connected with the customers as long as the internet is available. These tools now allow prompt communication with customers and suppliers. On the other hand, customers prefer online shopping because they don't have to wait for stores to open. They can shop whenever they want and arrange for delivery or pickup. Moreover, customer buying options are quick and convenient as they transfer funds online. Therefore, e-startups can start with relatively inexpensive and free social media tools, Facebook, Twitter, LinkedIn, etc. (Brooks, Heffner, \& Henderson, 2014). Knowledge and technologies associated with social media have become a significant component of business operations of many companies in their marketing, risk management, and customer relationship strategies (Brandel, 2010). Social media communications influence customer perceptions and purchase decisions (Edleman, 2010; Elzinga, Mulder, \& Vetvik, 2009). 
Today's businesses value digital networking as the means of viral marketing which allows information to be spread promptly from one to many through self-replication (Phillips, McFadden, \& Sullins, 2010). An eentrepreneur can also make use of the positive reviews and comments from the general public \& customers to build up his business furthermore. Digital networks can help him to enhance company exposure and obtain better decision-making information in order to optimize business processes (Brooks, Heffner, \& Henderson, 2014). The idea of e-entrepreneurship has eliminated many of the barriers that a traditional marketplace faces (Matlay \& Westhead, Virtual teams and the rise of e-entrepreneurship in Europe, 2005). E-startups benefit from the borderless market to the high-end technology. They enjoy access to the global marketplace from the very beginning. Physical stores are limited by the geographical area, but online stores can sell products and services across the world. In statista.com it was reported that, in 2017, Amazon's total consolidated net revenue was USD 177.9 billion, of which USD 54.3 billion were generated through international revenue channels.

Capital, in any business venture, is one of the major factors of production. E-entrepreneurs have the advantage of operating their businesses with less initial capital and a minimum fixed cost. They can collect money or take loans from their relatives for small scale operations. E-startups can save money since they don't have to pay for decorated office spaces, office maintenance, a range of utilities and salaries like other physical business organizations. Automated billing, inventory management and online banking also contribute to lowering the operational costs of E-startups. Every business has operational risks. The risk of ebusiness is much lower than any other physical businesses. One of the major benefits of e-business is that it's easy to scale the business quickly. An e-entrepreneur can work more closely and flexible with his suppliers and partners, and can offer any feedback to his customers' needs within a moment. They make a faster decision, which, in turn saves time. A growing business largely depends on its customer satisfaction. Internet and its ever-changing capabilities offer the beginners such possibilities so that they can expand their business strategically and opportunistically (Hunter \& Long, 2003).

\section{Challenges}

Adam Smith (1723-1790) identified land, labor and capital as the three factors of production in his Wealth of Nations (1776) which are the basic inputs needed for any business operation and internet startups are of no exceptions. Though the primary relevance of land and labor as factors of production has been diminished measurably due to technological advancement, the costs associated with these two factors still incur in different forms. Internet startups need office space \& equipment, warehouse, internet connection as well as labor hours to run their business. Entrepreneurs face challenges to meet these associated costs due to lack of liquid capital at the beginning (Blanchflower \& Oswald, 2007). Startups need capital to start business operation. Availing of bank loans, mostly through the long and troublesome procedure, is not always easy. To have adequate capital to start \& retain business is, therefore, always a big challenge (Brooks, Heffner, \& Henderson, 2014). Besides, technologies are subject to continual change which requires subsequent investments. Some economists considered entrepreneurship as the fourth factor of production, separate from labor. Jeremy Bentham (1748-1832) recognized the role of the entrepreneur in society (Landstrom, 2007). Jean Baptiste Say (1767-1832) presented a different approach of entrepreneurship as an input in the production process (Drucker, 1974; Landstrom, 2007). An entrepreneur, with his skill sets, mobilizes the resources and creates more wealth.

Most e-startups don't get very far. It's the entrepreneur himself who takes calculated risks to grow his business. It's imaginable that the beginners are lamentably naive in their actions. Beginners face challenges in timely decision making due to lack of entrepreneurial skills and they can't grow beyond their initial size because of their limited vision (Matlay \& Westhead, Virtual teams and the rise of e-entrepreneurship in Europe, 2005) and lack of confidence in their abilities. Furthermore, the issue of management was acknowledged by a number of economists as another spectrum of production. Alexander Hamilton (17571804), Comte de Saint-Simon (1760-1825), Francois Fourier (1772-1837), Henry Clay (1777-1852) and Alfred Marshall (1842-1924) attributed management as one of the factors of production (Drucker, 1974). A manager manages and organizes all the entrepreneurial activities coupled with other resources. Most of the times in a small enterprise, the management and managerial skills are neglected. The entrepreneur can't bear the cost of a manager and instead he becomes the manager. In a recent paper Ngige (2014) argued that 
managerial skills are different from entrepreneurial skills. Lack of experience and insufficient knowledge in business management may lead the business to failure. Ademola, Olaleye, Olusuyi \& Edun (2013) found that over $60 \%$ of small business failure in Nigeria is due to poor management practices.

Today the Internet is an open marketplace. The competition is very extensive since there is almost no barrier to new entrants and competitors in this market. Maguire (2002) attributed three types of risks that any project may face: risks associated with new technology, project size and failure. New technology almost creates a bubble. The dot-com collapse (1999-2001) saw hundreds of e-startups closed down or sold. If a startup sets short term ambitious goals and makes the business large beyond its capacity from the beginning, the risks associated with project size increases. If the business can be copied quickly by the competitors, there may be financial risks. The combination of basic business skills and expert knowledge, in this regard, therefore, is a key factor in the long run sustainability of e-business (Zhao, 2007). The Information Technology environment changes rapidly. It also requires regular support and maintenance. But eentrepreneurs mostly can't cope with the pace of the new technologies and sometimes they are incapable of making proper use of it. Old-fashioned e-marketing tools, limited exposure in social media, ineffective and outdated websites increase the cost of doing business. Hunter \& Long (2003), in support of this challenge, justifiably argued that technology is generally used for daily operations rather than strategic and competitive reasons.

Customers are the main focus of any business. What drives a customer to buy online? The answers usually include convenience, price and speed. But there are a few other factors that become more fundamental- trust and service. It is a big challenge for the startups to gain the customers' acceptance \& credibility since they separate the customer from the product or service in both time and space (Finkelstein, 2001). It's also very much critical for them to position their products within a short period of time. Most online startups struggle because of their inefficiencies in customer service. It is unfortunate that most of the entrepreneurs are skilled in a field other than marketing (Martin, 2009; Stokes, 2000; Zontanos \& Anderson, 2004). In most of the cases entrepreneurs initiate an idea and then try to find its market rather than market needs assessment. Marketing practice is about interrelated transactions which affect the success of entrepreneurial ventures. Many generally mistake marketing for advertising. However, advertising is only a key element of marketing mix-widely known as 4Ps: product, price, place and promotion (Kotler \& Armstrong, 2012). Beginners usually don't analyze these 4Ps of marketing. They prefer informal, short-cut methods than formal market research for gathering market information (Stokes, 2000). The advancement of internet technology has also changed the traditional marketing concepts to e-marketing. Today startups need considerable investment in search engine optimization, content marketing, public relations and paid advertising.

Though innovation and new product development is the key to dominate the market, most of the beginners don't pay attention to it. They take innovation and new product development as a pricy matter for them at this very stage. Those who are exceptions, face regular challenges of imitation and erosion from the competitors. In addition, some people start online businesses with fraudulent business intentions which return distrust among the customers and harden the roads of actual startups.

In many cases it has been seen that small businesses are only concerned with the particular opportunity (Hunter \& Long, 2003) and localized market (Matlay \& Westhead, Virtual teams and the rise of eentrepreneurship in Europe, 2005), thus preventing them from growing themselves big. Besides, increased competition from big and well-established companies is a major threat to the success of the startups. Big companies try to create a monopoly and drive the new one out of the market.

As the e-business organizations largely depend on internet-based technologies, management deals with never-ending information security threats every day. Data thefts, from inside or outside, have become one of the top security concerns across all organizations (McNurlin, Sprague, \& Bui, 2009). Because of new technologies, threats are getting more sophisticated and hackers are more creative in their attacks. Customers will not buy from a business if they find that the website crashes and the system becomes down regularly. Customers don't want their personal information, bank details and credit card numbers to be stolen. Therefore, it becomes expensive to implement an organization's security strategy and activities for the e-entrepreneurs who are very new in his business. 
Lastly, in many countries the government is not e-business friendly. The startups get limited support from the government. They meet tax regulations, marketing restrictions and poor infrastructure. These sorts of challenges mostly occur in developing countries where institutional support for e-business (startups and running) is meagre both quantitatively and qualitatively. E-entrepreneurs face challenges everywhere.

\section{Future of E-Startups}

Modern technologies have opened new opportunities \& replaced the existing market but the net economy becomes a fast-moving, highly uncertain and unpredictable trading environment (Matlay \& Westhead, Virtual teams and the rise of e-entrepreneurship in Europe, 2005). We are passing through the information age and information will dominate the near future. It has been argued by experts that Big Five companies: Google, Apple, Amazon, Facebook and Microsoft monopolize the web (Manjoo, 2017). We saw some of the best startups in the tech industry e.g. Uber, WhatsApp, Instagram, Snap, Twitter were obtained by these big companies in the end. The current trends foretell that the future also belongs to them. They dominate the app stores, cloud storages, Ad networks and most importantly- the data. Startups will have to pay most of their earnings to these companies just for existing. These big companies will accrue ever more capital and power, and startups will face unfair competition.

\section{Conclusion and Recommendations}

The purpose of this paper is to conceptualize-entrepreneurship while discussing its core features, potentials and challenges. E-entrepreneurship gives new business ideas, boosts new technologies, and creates successful businesses. Since there are a growing number of e-startups today, extensive research is needed to study how these firms effectively plan and incorporate new business processes and practices from a long-term perspective. Further research is also required to address emerging technologies e.g. electronic data interchange, data communication, artificial intelligence, and security-related technologies. The emergence of electronic business is not just the application of technology in business, but is a strategy to manage all related business functions creatively over the internet. However, ineffective management in ebusiness leads to inefficient use of business resources. Developing and maintaining managerial skill regularly through training and development in this regard is required. Young people are the main entrepreneurs of any business venture. They need entrepreneurship education which will enable them to get a good base of skills and practical knowledge. Entrepreneurship education in the school or undergraduate level will provide students with the skills and knowledge to come up with business ideas and develop their own ventures. Continuing business always requires a risk assessment, for which the startups need to consider periodic risk assessment to avoid some of the risks. Moreover, any business requires continuous dedication and a long-term business plan. More focus is needed in valuing of online startups. The competition in online business is extensive. Therefore, startups should change their strategies regularly in line with market needs, and competitions in order to gain market credibility.

\section{References}

Ademola, I. S., Olaleye, S. O., Olusuyi, A. E.\& Edun, F. (2013). Why small scale businesses failed as a remedy to unemployment problem in Nigeria. Journal of Humanities and Social Science, 8(4), 68-93.

Blanchflower, D. G.\& Oswald, A. J. (2007). What Makes a Young Entrepreneur, IZA Discussion Papers 3139. Institute for the Study of Labor (IZA).

Brandel, M. (2010). Are you LISTENING? Computerworld, 44(13), 13-15.

Brooks, G., Heffner, A.\& Henderson, D. (2014). A SWOT analysis of competitive knowledge from social media for a small start-up business. The Review of Business Information Systems (Online), 18(1), 23.

Drucker, P. F. (1974). Management: Tasks, Responsibilities, Practices (1st ed.). New York: Truman Talley Books, E. P. Dutton.

Edleman, D. (2010). Branding in the digital age: You're Spending Your Money in All the Wrong Places. Harvard Business Review, 88(12), 62-69.

Elzinga, D., Mulder, S.\& Vetvik, O. J. (2009). The consumer decision journey. McKinsey Quarterly, 3, 96-107.

Finkelstein, S. (2001). Internet startups: so why can't they win? Journal of Business Strategy, 22(4), 16-21. 
Hébert, R. F.\& Link, A. N. (1989). In search of the meaning of entrepreneurship. Small business economics, 1(1), 39-49.

Hunter, M. G.\& Long, W. A. (2003). Adopting the entrepreneurial process in the study of information systems and small business. In Managing IT in government, business \& communities (pp. 1-14). IGI Global.

Kollmann, T. (2006). What is e-entrepreneurship?-fundamentals of company founding in the net economy. International Journal of Technology Management, 33(4), 322-340.

Kotler, P.\& Armstrong, G. (2012). Principles of Marketing (14th ed.). Pearson Education.

Landstrom, H. (2007). Pioneers in entrepreneurship and small business research (Vol. 8). Springer Science \& Business Media.

Maguire, S. (2002). Identifying risks during information system development: managing the process. Information Management \& Computer Security, 10(3), 126-134.

Manjoo, F. (2017, 10 18). Retrieved from The New York Times: https://www.nytimes.com/2017/10/18/technology/frightful-five-start-ups.html

Manuel, E. (2006). e-Entrepreneurship. Munich Personal RePEc Archive, Paper No. 2237(13). Retrieved from https://mpra.ub.uni-muenchen.de/2237/1/MPRA_paper_2237.pdf

Martin, D. M. (2009). The entrepreneurial marketing mix. Qualitative Market Research: An International Journal, 12(4), 391-403.

Matlay, H. (2004). E-entrepreneurship and small e-business development: towards a comparative research agenda. Journal of Small Business and Enterprise Development, 11(3), 408-414.

Matlay, H.\& Martin, L. M. (2009). Collaborative and competitive strategies in virtual teams of e-entrepreneurs: A pan-European perspective. Australasian Journal of Information Systems, 16(1).

Matlay, H.\& Westhead, P. (2005). Virtual teams and the rise of e-entrepreneurship in Europe. International Small Business Journal, 23(3), 279-302.

McNurlin, B., Sprague, R. H.\& Bui, T. (2009). Information Systems Management in Practice (8th ed.). Pearson Education, Inc.

Meyer, G. D., Neck, H. M.\& Meeks, M. D. (2017). The entrepreneurship-strategic management interface. In Strategic entrepreneurship: Creating a new mindset (pp. 17-44). Oxford, UK:Blackwell.

Ngige, C. D. (2014). Management as a Factor of Production and as an Economic Resource. International Journal of Humanities and Social Science, 4(6), 162-166.

Phillips, M., McFadden, D. T.\& Sullins, M. (2010). How effective is social networking for direct marketers. Journal of Food Distribution Research, 41(1), 96-100.

Reynolds, P. D. (2005). Understanding business creation: Serendipity and scope in two decades of business creation studies. Small Business Economics, 24(4), 359-364.

Rumelt, R. P. (2005). Theory, strategy, and entrepreneurship. In Handbook of entrepreneurship research (pp. 11-32). Springer, Boston, MA.

Sharma, M., Pathak, D.\& Chowhan, S. (2014). E-Business: Strategic Management Practice for New Entrepreneurship. Social Science Research Network.

Stokes, D. (2000). Entrepreneurial marketing: a conceptualisation from qualitative research. Qualitative market research: an international journal, 3(1), 47-54.

Turban, E., King, D., Lee, J. K., Liang, T. P.\& Turban, D. C. (2015). Electronic commerce: A managerial and social networks perspective (8th ed.). Springer.

Zhao, F. (2007). Issues and challenges facing e-entrepreneurship and e-innovation. 18th Annual Information Resources Management Association International Conference (pp. 945-948). IGI Global.

Zontanos, G.\& Anderson, A. R. (2004). Relationships, marketing and small business: an exploration of links in theory and practice. Qualitative market research: an international journal, 7(3), 228-236. 